\title{
IMPLEMENTATION OF GOVERNMENT POLICIES TO HANDLING THE COVID-19 PANDEMIC IN INDONESIA
}

\author{
Tivalen Dwirara Anggraini \\ Master of Public Health, Faculty of Public Health, Muhammadiyah University of Jakarta \\ Jl. K.H Ahmad Dahlan, Cirendeu, Ciputat Timur, Tangerang Selatan, Banten 15419 \\ E-mail: valendwirara@gmail.com
}

\begin{abstract}
The spread and addition of COVID-19 cases are certainly dangerous. Government policies and commitments from the community play an important role in the process of accelerating the handling of COVID-19. This study aims to review the policies that have been issued by the government to deal with the COVID-19 pandemic and the public to these policies. The method used in this study is a literature review. The results of this study indicate that various policies have been issued by the government in handling COVID-19 such as policies for implementing health protocols, Large-Scale Social Restrictions, and policies for fulfilling COVID-19 vaccinations in the community. The research concludes that the government and the role of the community are very important that their existence greatly influences the implementation of these policies. Public awareness is the key to success in breaking the transmission of the coronavirus, the government needs to make firm policies in efforts to handle COVID-19, and education to the public must be carried out massively.
\end{abstract}

Keywords: COVID-19, Government Policy, Handling COVID-19, COVID-19 in Indonesia 
E-ISSN: 2808-5361

http://e-journal.fkmumj.ac.id/
Proceeding The First Muhammadiyah Internasional- Public Health and Medicine Conference

\section{INTRODUCTION}

COVID-19 is a respiratory disease that is contagious and spreads throughout the world, including Indonesia. This disease started from a patient identified as SARS-CoV-2, who was exposed to a seafood market in Wuhan city, Hubei Province, China in December 2019. On January 30, 2020, the World Health Organization (WHO) declared the incident COVID-19 as an Emergency. Public Health Emergency of International Concern (PHEIC) and on March 11, 2020, WHO has declared COVID-19 as a pandemic ${ }^{2}$.

On January 27, 2020, Indonesia issued travel restrictions from Hubei Province, which is the epicenter of the emergence of COVID-19, and evacuated 238 Indonesians who were in Wuhan. The first case of COVID-19 infection in Indonesia was reported on March 2, 2020. The initial spread was from an event in Jakarta where the patient was in contact with a foreign citizen (WNA) from Japan living in Malaysia. After the meeting, the patient complained of fever, cough, and shortness of breath ${ }^{3}$.

The spread of COVID-19 cases continues to increase to date, namely, on May 12, 2021, it was reported as many as 1,728,204 (4608 new cases) confirmed COVID-19, 47,617 (152 new) deaths and 1,584,878 cases recovered from 510 districts in 34 provinces $^{4}$. This data shows that this case continues to increase from the first case of COVID-19 infection in Indonesia, namely in 2020 until now, in 2021, it has not shown significant changes.

The spread and addition of COVID-19 cases are certainly dangerous because it affects multidimensional aspects such as health, education, economy, social, politics, culture, and so on, both materially and non-materially, so serious handling is needed to suppress the spread of COVID-19 infection. Government policies play an important role in the process of accelerating the handling of COVID-19. The government basically cannot avoid cases of death due to COVID-19, however, the government must maximize efforts to protect its people through various policies issued. However, only good policy is not enough in handling COVID-19. Commitment from the civilization is the key for handling COVID-19 to comply with the rules and policies that have been issued by the Government. Community compliance will only appear if the civilization has the same belief and trust as the government. Because of these, this paper reviewed the policies that have been issued by the government and the public's response to this policies 5 .

\section{METHODS}


The method used in this study is a literature review. A literature review is a literature research search by reading various books, journals, and other publications related to the research topic, to produce an article related to a particular topic or issue ${ }^{6}$.

\section{RESULTS AND DISCUSSIONS}

The government of Indonesia is considered late in making efforts to deal with COVID19 because before the discovery of positive cases in Indonesia, the President issued four instructions as a step to anticipate the impact of COVID-19 on the economy, namely by increasing domestic conference activities, MICE (meetings, incentives, conventions, and exhibitions), increasing tourism promotion to tourists who cancel visiting China, Korea, and Japan, and preparing 72 billion to pay influencers to promote Indonesia as a tourist destination. While other countries limit the number of visitors, Indonesia opens up opportunities for tourists to visit on the grounds of increasing the economy. However, after the positive cases of COVID19 increased, several government policies began to changes.

The first policy carried out by Indonesia was to issue travel restrictions from the center of COVID-19, namely Hubei province. At the same time, Indonesia also evacuated 238 Indonesians from Wuhan. Furthermore, on March 3, 2020, appointed 100 domestic public hospitals as Referral Hospitals and increased the number of Referral Hospitals to 227 to cope with the increasing number of COVID-19 patients on March 8, 20203. Provide free personal protective equipment (PPE) for homes COVID-19 referral hospital ${ }^{5}$.

The government of Indonesia implements social distancing measures for the community and provides the principles of the current health protocol known as the $5 \mathrm{M}$, namely using masks, washing hands/hand sanitizers, keeping distance, staying away from the crowded situation, and reducing mobility ${ }^{7}$. In addition, it also increases body resistance, consumes balanced nutrition, manages comorbid diseases, and pays attention to vulnerable groups as well as clean and healthy living behavior. However, in reality, many people do not comply with the health protocols given in the face of the COVID-19 pandemic. The Central Statistics Agency (BPS) reported the results of a survey on the level of community compliance in implementing health protocols during the Covid 19 pandemic, the results showed that the majority did not comply with health protocols. as many as $55 \%$ of respondents stated that there were nothing strict punishments, and as many as $33 \%$ of respondents did not comply because it made their work difficult, and $23 \%$ said the prices of masks, face shields, and other protective equipment were expensive. In addition, the Government of DKI Jakarta recorded that the total fines that 
E-ISSN: 2808-5361

http://e-journal.fkmumj.ac.id/
Proceeding The First Muhammadiyah Internasional- Public Health and Medicine Conference

violate the health protocols of DKI Jakarta residents reached Rp. 4.9 billion since June 2020. 13,300 violators did not use masks from 12-24 October $2020^{8}$.

The government has also implemented a large-scale social restriction (PSBB) policy based on Government Regulation Number 21 of 2020 concerning Large-Scale Social Restrictions (PSBB) in the context of accelerating the handling of Corona Virus Disease 2019 (Covid-19). PSBB is a restriction on certain activities of residents in an area suspected of being infected with COVID-19 in such a way as to prevent the possibility of spreading the virus. PSBB regulates school and workplace holidays; religious activity; activities in public places or facilities; social and cultural activities; modes of transportation, as well as restrictions on other activities specifically related to defense and security aspects 9 . However, the implementation of this policy hurts society because the economic strength of the society continues to weaken. The effect of this has resulted in many things, such as many companies closing, layoffs, many students dropping out of school and college, increasing unemployment, and finally increasing poverty rates ${ }^{10}$. The number of closures in the economic sector has made the lower classes of a society increasingly experience a slump, causing many of them to violate government policies to stay indoors. Violations of the ban on going home ahead of Eid because the implementation of the lockdown is also not very effective because of the many reports of COVID-19 cases originating from travelers from outside the region. Although the government has also made efforts to provide social assistance in the form of cash with Direct Cash Assistance (BLT) and basic daily needs, many levels of society have not felt it evenly due to incomplete data collection $^{11}$. The government needs to make a study on economic problems that must be considered carefully.

The government is currently trying to meet the target of fulfilling the COVID-19 vaccination in society. This vaccine will become a commodity (become a trade item) that has economic value. Therefore, there must be a legal instrument that regulates this mechanism. Research on Coronavas Clinical Trials and Mass COVID-19 Vaccination Plans in Indonesia explains that the vaccination plan to be carried out is an effective step in controlling disease transmission. The goal is for protecting public health from the threat of COVID-19, besides that in the long term it is projected to be able to reduce the current social and economic impacts that have arisen due to the COVID-19 pandemic. However, if traced from several previous studies, there is a lack of studies regarding mass vaccination (COVID-19 vaccine) for society and the emphasis is that the vaccination process is an effort by the community to comply with the law (Obedience law). When referring to laws regulation, for example in Article 14 of Law Number 
14 of 1984 concerning Outbreaks of Infectious Diseases and Article 9 and Article 93 of Law Number 6 of 2018 concerning Health Quarantine there are criminal sanctions for people who refuse it. But interestingly, Law Number 36 of 2009 concerning health (referring to Article 5) says that "Everyone has the right to be independent and to determine their health services for themselves", which can indirectly explain if this vaccination can be an option. for someone in doing treatment (private rights) ${ }^{9}$. The acceptance of the COVID-19 vaccination has become a matter of controversy. Many countries take action against it because it is considered ineffective. The lack of information experienced by the public and the government's lack of alertness to educate related to vaccinations has led to public rejection of the COVID-19 vaccine. Previous research has shown that public trust in government is very low regarding vaccine acceptance and can contribute to public compliance with recommended measures13. People are still afraid to participate in this vaccination program so that education is needed on an ongoing basis so that the vaccination program can meet the target and return to social activities as usual.

\section{CONCLUSION AND SUGGESTIONS}

This study shows various policies that have been carried out by the government. However, the focus of this study is to discuss government policies in the policy of implementing the Health Protocol for Large-Scale Social Restrictions, and policies for fulfilling COVID-19 vaccinations in the community. Based on the results of the study that has been carried out, it shows that the role of society is very important that its existence greatly influences the implementation of the policy. Public awareness is the key to success in stopping the transmission of the coronavirus.

The government needs to make firm policies in efforts to handle COVID-19, and education to the public must be carried out massively.

\section{GREETING THANKYOU}

Thanks to the Muhammadiyah University of Jakarta, and especially to Dr. Dewi Purnamawati, SKM., MKM who has given many supports and guidance in the preparation of this literature review.

\section{REFERENCES}

1. Shi Y, Wang G, Cai X, Deng J, Zheng L, Zhu H, et al. An overview of COVID-19. 2020;21(5):343-60.

2. Kesehatan K. Pedoman Pencegahan dan Pengendalian Corona Virus deases (Covid-19). Kementrian Kesehat [Internet]. 2020;5:178. Available from: 
E-ISSN: 2808-5361

http://e-journal.fkmumj.ac.id/
Proceeding The First Muhammadiyah Internasional- Public Health and Medicine Conference

https://covid19.go.id/storage/app/media/Protokol/REV-05_Pedoman_P2_COVID-

19_13_Juli_2020.pdf

3. Putri RN. Indonesia dalam Menghadapi Pandemi Covid-19. J Ilm Univ Batanghari Jambi. 2020;20(2):705.

4. World Health Organization Indonesia. Coronavirus disease 2019 (COVID-19). WHO Indones Situat Rep - 55. 2021;55:1-24.

5. Harirah MS Z, Rizaldi A. Merespon Nalar Kebijakan Negara Dalam Menangani Pandemi Covid 19 Di Indonesia. J Ekon dan Kebijak Publik Indones. 2020;7(1):36-53.

6. Marzali A. Menulis Kajian Literatur. ETNOSIA J Etnogr Indones. 2017;1(2):27.

7. Pratama O. Pembinaan Kader Kesehatan dalam Upaya Peningkatan Kesehatan Lansia di Era Pandemi Covid. Bina Sehat Masy. 2021;1(1):19-23.

8. Triana M, Kajian PM, Nasional K, Stratejik K, Global D, Imam A, et al. Kebijakan Pemerintah Dki Jakarta Menangani Pandemi Covid-19. J Ilmu Pemerintah. 2021;14(1):1-9.

9. Anung Ahadi Pradana, Casman N. Pengaruh Kebijakan Social Distancing pada Wabah COVID-19 terhadap Kelompok Rentan di Indonesia. J Kebijak Kesehat Indones JKKI [Internet]. 2020;9(2):61-7. Available from: https://jurnal.ugm.ac.id/jkki/article/view/55575

10. Fatkhurohman, Sirajuddin. Peran Negara Dan Rakyat Dalam Menanggulangi Dan Mencegah Pandemi COVID 19. Conf Innov Appl Sci Technol (CIASTECH 2020) [Internet]. 2020;219-28. Available from: http://publishing-widyagama.ac.id/ejournalv2/index.php/ciastech/article/view/1870

11. Dewi DS, Tobing TNW. Optimalisasi Penyelenggaran Pelayanan Publik Dalam Masa Perubahan Melawan Covid-19 Di Indonesia. J Inf Syst Applied, Manag Account Res. 2021;5(1):210.

12. Rahman YA. Vaksinasi Massal Covid-19 sebagai Sebuah Upaya Masyarakat dalam Melaksanakan Kepatuhan Hukum (Obedience Law). Khazanah Huk. 2021;3(2):80-6.

13. Yanti, Paradiksa S. Jurnal Keperawatan \& Kebidanan Jurnal Keperawatan \& Kebidanan. J Keperawatan. 2021;13(1):213-26. 